\title{
Exploring ubuntu discourse in South Africa: Loss, liminality and hope
}

\begin{tabular}{|c|c|}
\hline \multicolumn{2}{|c|}{$\begin{array}{l}\text { Author: } \\
\text { John L.B. Eliastam }{ }^{1}\end{array}$} \\
\hline $\begin{array}{l}\text { Affiliation: } \\
{ }^{1} \text { Department } \\
\text { Theology, Uni } \\
\text { Pretoria, Sout }\end{array}$ & $\begin{array}{l}\text { of Practical } \\
\text { versity of } \\
\text { h Africa }\end{array}$ \\
\hline $\begin{array}{l}\text { Corresponden } \\
\text { John Eliastam }\end{array}$ & ce to: \\
\hline $\begin{array}{l}\text { Email: } \\
\text { john@smartcl }\end{array}$ & hoices.co.za \\
\hline $\begin{array}{l}\text { Postal addres } \\
\text { PO Box } 19460 \\
\text { East London, }\end{array}$ & $\begin{array}{l}\text { s: } \\
\text { Secoma 5214, } \\
\text { South Africa }\end{array}$ \\
\hline $\begin{array}{l}\text { Dates: } \\
\text { Received: } 16 \\
\text { Accepted: } 20 \\
\text { Published: } 19\end{array}$ & $\begin{array}{l}\text { Apr. } 2015 \\
\text { June } 2015 \\
\text { Jut }\end{array}$ \\
\hline $\begin{array}{l}\text { How to cite th } \\
\text { Eliastam, J.L.B } \\
\text { 'Exploring ubu } \\
\text { in South Afric } \\
\text { liminality and } \\
\text { et Ecclesia } 36 \text { ( } \\
8 \text { pages. http: } \\
10.4102 / \text { ve.v3 }\end{array}$ & $\begin{array}{l}\text { is article: } \\
., 2015 \text {, } \\
\text { Intu discourse } \\
\text { a: Loss, } \\
\text { hope', Verbum } \\
\text { 2), Art. \#1427, } \\
\text { //dx.doi.org/ } \\
6 \mathrm{i} 2.1427\end{array}$ \\
\hline $\begin{array}{l}\text { Note: } \\
\text { This article wa } \\
\text { part of the res } \\
\text { PhD degree th } \\
\text { under supervi } \\
\text { Julian C. Mülle } \\
\text { of Practical Th } \\
\text { University of } \\
\text { South Africa. }\end{array}$ & $\begin{array}{l}\text { s written as } \\
\text { iearch for the } \\
\text { sion of Prof. } \\
\text { sion Department } \\
\text { eology, } \\
\text { Pretoria, }\end{array}$ \\
\hline $\begin{array}{l}\text { Research Part } \\
\text { Ubuntu-Resea } \\
\text { the University }\end{array}$ & $\begin{array}{l}\text { icipant in the } \\
\text { rrch project of } \\
\text { of Pretoria. }\end{array}$ \\
\hline $\begin{array}{l}\text { Copyright: } \\
\text { C 2015. The A } \\
\text { Licensee: AOS } \\
\text { OpenJournals } \\
\text { licensed unde } \\
\text { Commons Att } \\
\text { License. }\end{array}$ & $\begin{array}{l}\text { Authors. } \\
\text { IS } \\
\text { This work is } \\
r \text { the Creative } \\
\text { ribution }\end{array}$ \\
\hline $\begin{array}{l}\text { Read online: } \\
\text { 口 }\end{array}$ & $\begin{array}{l}\text { Scan this QR } \\
\text { code with your } \\
\text { smart phone or } \\
\text { mobile device } \\
\text { to read online. }\end{array}$ \\
\hline
\end{tabular}

This article explores the current state of the social value of $u b u n t u$. The notion of $u b u n t u$ seems to offer possibilities for nation building and social cohesion in post-Apartheid South Africa. However, this is contested by scholars who argue that the concept is vague and open to abuse. Interviews reveal that, whilst core elements remain, the meaning of $u b u n t u$ has been eroded, and is subject to distortion and even abuse. Ubuntu exists tightly interwoven with un-ubuntu. The notion of liminality is introduced to understand the current state of both ubuntu and South African society in transition. A liminal space offers possibilities for the creative re-imagining and recovery of $u b u n t u$ as a social value that can drive social transformation in South Africa. The lens of discursive leadership offers insight into the ways in which leaders can stimulate and shape $u b u n t u$ discourse and facilitate the construction of new meaning in society.

Intradisciplinary and/or interdisciplinary implications: The article forms part of broader research into perceptions of difference and threat, and prejudice on the part of South Africans towards foreigners. Ubuntu is a social value that should challenge prejudice and xenophobia and shape social relationships. Research in a rural and urban context in the Eastern Cape suggests that $u b u n t u$ discourse has been eroded and is in need of reinvigoration.

\section{Introduction}

Is the African social value of $u b u n t u$ dead? Does it offer any hope for transforming South African society or fostering social cohesion? Is it able to play a meaningful role in the building of a post-Apartheid South African society that embodies reconciliation and is based on principles of justice and equality? Whether ubuntu could (or should) play such a role has been debated. Within the broad spectrum of positions, there are two generally opposing viewpoints amongst academics:

- there are those who argue that, as a foundational principle in African philosophy, ubuntu offers significant possibilities for the transformation of South African society

- on the other side, there are those who argue that $u b u n t u$ is vague, full of contradictions, and subject to manipulative and even nefarious use.

This article will outline both of those positions, and based on an investigation of people's understandings of $u b u n t u$ in a specific context, argue that the notion of $u b u n t u$ appears to have been eroded to the extent that it currently seems unable to play a meaningful role in nationbuilding.

Where does this leave $u b u n t u$ ? I will borrow the concept of liminality from anthropology and argue that, as a society that has undergone discontinuous change, South Africa is in a liminal space, as is the notion of ubuntu. Within this space there is both threat and possibility. There is the threat that the erosion of positive social values will continue and that our already fragmented society will tear itself apart. There is also the possibility that we can creatively recover both the meaning and force of $u b u n t u$, and find significant ways to embody it in our society.

\section{Ubuntu in an emerging society}

The birth of a democratic South Africa in 1994 created hope for healing and transformation in South Africa. The leadership of Nelson Mandela was an example and an inspiration that gave impetus towards forgiveness and reconciliation. Desmond Tutu spoke of a 'Rainbow Nation', a phrase that encapsulated a vision for the future of South Africa that was full of possibility and hope. The notion of ubuntu has been central to attempts to build a transformed, just society.

The desire to find something uniquely African upon which to build postcolonial or postconflict African societies is not unique. As African countries have emerged from colonial rule and attempted to transform their societies, this has often included attempts to return to something 
from their past that is deemed to be noble or worthy. Gade (2011:304-305) observes that these narratives of return tend to divide history into three phases: the precolonial age which is often conceived of as a time of near perfect harmony and prosperity; a second phase in which outsiders steal the resources, dignity and culture of African people; and a third phase of recovery in which African dignity and culture is restored. Ubuntu discourses in South Africa fit into this broader category of narratives of return (Gade 2011; Matolino \& Kwindingwi 2013).

\section{Ubuntu as central to African life}

The principles of $u b u n t u$ resonate with universal values of human worth and dignity. Archbishop Emeritus Desmond Tutu (1999:34-35) explains that the meaning of ubuntu is that, 'a person is a person through other people. It is not "I think therefore I am". It says rather: "I am human because I belong". I participate, I share'. The concept highlights the interconnectedness of human society, with the implication that people should treat others as part of the extended human family.

Ubuntu has been translated as 'humanity' (Shutte 2001:2), 'African humanness' (Broodryk 2002:13), 'humanism or humaneness' (Mnyaka \& Motlhabi 2009:63), or 'the process of becoming an ethical human being' (Mkhize 2008:35).

Prinsloo (1998:41-45) describes various understandings of ubuntu in the South African context. Chikanda (1990) sees ubuntu as African humanism. It involves sensitivity to the needs of others, charity, sympathy, care, respect, consideration and kindness. For Khoza (1994), ubuntu is an African view of life and the world in which people share and treat each other as humans, based on an underlying 'universal brotherhood' of Africans.

In Mkhize's (2008:43) understanding, ubuntu 'incorporates ideas of social justice, righteousness, care, empathy for others and respect'. Mnyaka and Motlhabi (2009:74) write that ubuntu 'is inclusive ... it is best realised in deeds of kindness, compassion, caring, sharing, solidarity and sacrifice'. Makhudu (1993) writes as follows:

Every facet of African life is shaped to embrace ubuntu as a process and philosophy which reflects the African heritage, traditions, culture, customs, beliefs, value system and the extended family structures. (p. 40)

Mcunu (2004:25) presents ubuntu as the ideal stage of being a human being; it is the 'best way of being a person according to African understanding of the human person'.

Louw (2001) points out that whilst these translations involve a loss of culture-specific meaning:

The maxim 'ubuntu ngumumntu ngabantu' articulates a basic respect and compassion for others ... As such, it is both a factual description and a rule of conduct or social ethic. It not only describes human being as 'being-with-others', but also prescribes how we should relate to others, i.e. what 'being-withothers' should be all about. (p. 15)

\section{For Gathogo (2008), ubuntu:}

$[C]$ an be interpreted as both a factual description and a rule of conduct or social ethic. It both describes human beings as 'beingwith-others' and prescribes what 'being-with-others' should be all about. (p. 46)

Cornell and Van Marle (2005:207) capture this when they describe $u b u n t u$ as 'an ontic orientation within an interactive ethic'.

\section{Advocates of ubuntu as a guiding principle}

Given the historical meaning and significance of $u b u n t u$, it is hardly surprising that the notion has strong appeal within a post-Apartheid South African context.

The Interim Constitution of the Republic of South Africa (1993) spoke of the need for ubuntu rather than retribution. The Batho Pele (i.e. 'people first') principles that promote service delivery in the public sector are based on ubuntu. An example of this can be seen in the Department of Education's Service Delivery Plan (2007/2008). Ubuntu was the foundation of the Moral Regeneration Movement that was launched in South Africa in 2002 (Matolino \& Kwindingwi 2013:200).

Ubuntu has been harnessed in many ways:

- as a constitutional value that can be operationalised in law (Bekker 2006; Mokgoro 1998)

- as a philosophical basis for constitutional democracy (De Gruchy 2011)

- as foundation for moral theory (Metz 2007; Shutte 1993)

- as the basis for public policy (Nkondo 2007)

- as a guiding principle for citizenship education (Letseka 2012)

- as a normative value for education (Higgs 2003; Venter 2004)

- $\quad$ as the basis for business ethics (Lutz 2009; West 2014)

- as a model for management (Mbigi 1992; eds. Van den Heuwel, Mangaliso \& Van den Bunt 2007)

- as the basis for an African approach to conflict resolution and peace building (Murithi 2006)

- as a theological motif (Tutu 1999)

- as the framework for a theology of relational ontology (Forster 2010).

This list is by no means exhaustive, but it is indicative of the wide scope of application that is proposed by the advocates of ubuntu. Shutte (2001) and Broodryk (2002) have argued that ubuntu should be exported to the rest of the world as Africa's unique gift to humanity.

It seems clear that ubuntu has a rich and even provocative meaning. It is also evident that ubuntu resonates with a number of theological motifs, including the imago Dei, the church as the body of Christ, instructions to love one's neighbour, and the practical expressions of early Christian fellowship in the book of Acts. It is a social value from our African context that seems to reflect the orientation towards 
other human beings that the Gospel requires of those who follow Jesus Christ. If embraced and lived out, ubuntu could be a powerful driver of meaningful reconciliation, justice and healing in South African communities.

\section{Concerns about ubuntu as a guiding principle}

Enslin and Horsthemke (2004) are suspicious of some of the claims and principles associated with ubuntu. Ubuntu is specieist because of its focus on human beings. There are questions about whether it can include other cultures. They argue that ubuntu is contradicted, or weakened by the prevalence in Africa of autocratic rule, corruption, sexism, homophobia and the degradation of the environment. Furthermore, they question the value of ubuntu as a practical guide for policies or actions, arguing that it does not offer practical guidance for issues such as wasteful public expenditure or HIV and/or AIDS education. They conclude that ubuntu does not offer a solution as a foundation for a uniquely African form of democracy and question its value in citizenship education.

Cornell and Van Marle (2005:196) mention various criticisms that have been levelled against $u b u n t u$. These acknowledge the meaning it once had as a social value, but question its relevance today, especially to young South Africans. It is argued by some that ubuntu is inherently patriarchal and conservative. Its usefulness as a guiding principle for South African society is also diminished by its vagueness and ability to accommodate a range of meanings.

Matolino and Kwindingwi (2013:197) criticise what they call the 'aggressive promotion of $u b u n t u$ ' in post-Apartheid South Africa. They argue that history has shown that the use of such narratives of return to promote black identity has always resulted in failure. What it means to be 'African' is homogenised and alternative interpretations are suppressed as a hegemony is created around an ideal African way of being. They point to the massive disconnect between the ideals of $u b u n t u$ and the lived reality of most South Africans.

Matolino and Kwindingwi (2013:200-201) observe that through misappropriation and overuse, 'the notion of ubuntu has enjoyed such popular appeal that it can be said that it has become anything to anyone who so wishes to deploy it'. It is an outdated notion and there are greater dangers associated with its attempted revival than there are benefits. They conclude that ubuntu does not have the capacity to shape ethics in the current South African context. For the authors, attempting to return to the old is dangerous because of the elitist political agendas behind this, and faulty because what worked in Africa then is not suitable for a now that has been shaped by urbanisation and modernity. Whilst there is no fault with the ideal of ubuntu itself, it is not suited to the social and ethical challenges of our current situation.

Setiloane (1998:75) argues that an African worldview places a significant emphasis on the 'wholeness of all being'. Humanity, god, spirit powers, the ancestors and the created order are connected. Ubuntu plays a role in the interconnectedness that Setiloane describes. This links it strongly to a number of cultural practices that contradict more universal ubuntu ideals that may be extrapolated from the original cultural understanding of $u b u n t u$.

Matolino and Kwindingwi (2013:204) point out that, 'some of the most dedicated adherents of ubuntu would not be comfortable with some of the rights that are defended by the bill of rights/the constitution'. Ubuntu does not make all people equal. The cultural system that is said to be an expression of ubuntu relegates women to a lower social status. This is seen particularly in the regulation of customary marriage, access to land, and inheritance rights. Ubuntu seems to exclude certain groups from the scope of its benefits.

This raises the question of the extent of ubuntu. How wide do its boundaries stretch? Gathogo (2008) captures the dilemma as follows:

Primarily, ubuntu expresses itself well in the provision of assistance to 'our people' who may mean - the members of the blood relatives, tribemates, clanmates, political camp mates, social camp mates, and so forth. This has its obvious dangers in that the criterion in determining who is 'Our person' and 'who is not one of us' is indeed a tricky one. (p. 47)

Naude (2013:246) argues that when $u b u n t u$ is interpreted in a narrow or ethnic fashion it becomes corrupted. It is reduced to the use of one's power to benefit those close to you. 'We' is limited to those in my family, tribe or political party and ubuntu becomes a system of patronage that is used to pursue power and money. Naude adds that there are signs that ubuntu has disappeared completely and traces this to factors such as the damage done by colonialism to African identity, cultural globalisation and the encroachment of modernity on traditional African culture. Naude (2013) describes the results of this in our society:

The weak and the vulnerable fall by the wayside; the old sit alone; those dying of AIDS are socially shunned; foreigners many of them desperate - are attacked; and tax money (the small proportion that does reach the state's coffers in many African countries) is spent on sport stadiums and airports for the rich and benefits for the ruling elite, instead of being invested in education and basic health care for the poor. (p. 246)

One could reflect on the murder rate in South Africa, the incidence of rape and child rape, violent acts of xenophobia, corruption and nepotism, and legitimately question the existence of $u b u n t u$ or its power as a social value.

\section{Ubuntu on the ground Interviews}

Both the nature and the usefulness of ubuntu are clearly contested. However, much of this debate is taking place on a theoretical level, and this made me curious about how ordinary people understand the nature and relevance of $u b u n t u$. If a social system is an accurate reflection of the values that it embraces, what conclusions could be reached 
about the dominant values in South African society, given the existence of so much that contradicts and defies the spirit of $u b u n t u$ ? I wanted to explore this further by asking a range of people about their understanding of ubuntu and their experiences of it. I interviewed 20 people in East London, from a range of age groups. Eight of the respondents were unemployed and two were students, the other 10 worked in the public sector. As a narrative researcher, my goal is not to make generalisations about $u b u n t u$, but rather to listen deeply to people's stories in order to explore their meaning.

All of those I spoke to defined ubuntu in familiar terms: hospitality, compassion, humaneness, sharing and respect:

- 'Ubuntu is about treating people with respect, it's about courtesy and compassion.' (Respondent 3)

- 'My child is your child.' (Respondent 6)

- 'If you want to see ubuntu you will find it in socialism. It's when we are sharing.' (Respondent 8)

- 'Ubuntu can't be defined, but speaks for itself in action.' (Respondent 10)

- 'Ubuntu is a general term, and it is associated with your heart. How do you feel about others, how do you see the whole community you are sharing, you see? If there is empathy, take yourself to the shoes of that person. If it were you, how would you feel? Ubuntu is something in a person's heart.' (Respondent 12)

I asked people to tell me recent stories of ubuntu from their communities:

- 'There is an old woman in my community who is using her pension money to feed the street kids. You see? Every day she is feeding those children something. That is ubuntu. She is poor, but she has ubuntu.' (Respondent 4)

- 'If you look at the people who are feeding and caring for the mineworkers who are striking. That is ubuntu.' (Respondent 10)

This was a reference to the assistance that was being given to workers who were struggling because of the impact of a prolonged strike on platinum mines in 2014. A notable example of this was Seipati Mmekwa, who is married to one of the striking workers. She used her husband's pension to start a soup kitchen to feed miners and their families, some of whom were going for days without food (South African Press Association 2014).

The following reflects a traditional expression of $u b u n t u$ that was described to me:

- 'Where I live I slaughtered a cow. Then all of my neighbours come with dishes to get meat. It is not their cow, but the meat is for all of us because no one should be hungry. So each person will take what they need and we share the meat.' (Respondent 1)

I asked if this kind of practice was still common. Only one person still believed that this version of $u b u n t u$ is a powerful force in shaping social behaviour in South Africa:

- 'It's poverty now, you see now if you have something you are going to keep it for yourself because of poverty. But in those days everyone would share ... meat, mealies, everything ... but those days, they are gone.' (Respondent 5)

- 'Poverty is killing ubuntu, because people they don't care about another human being. They will rob and kill just to get something for themselves.' (Respondent 3)

- 'What we understand as ubuntu today is very different of our great grandparents understood it.' (Respondent 15)

Is $u b u n t u$ for everyone?

- 'Everybody can experience ubuntu. If you are a human being I must treat you with ubuntu.' (Respondent 1)

- 'No, it isn't. It is for our people.' I asked what was meant by 'our people', and the Respondent laughed in response. 'You must know what I mean [pause] it's the people in our community. White people do not understand ubuntu, they do not want ubuntu. Even we show them ubuntu in 1994 but they cannot show it.' (Respondent 8)

- 'Ubuntu is for Africans. White people must go back to Europe where they come from.' (Respondent 14)

Would a Zimbabwean living in South Africa be shown ubuntu?

- 'Yes, you will see that even a taxi driver will sometimes let that foreigner ... maybe he has only five Rand and the fare is eight Rand, but he can still come on that taxi because that is ubuntu.' (Respondent 2)

- 'No, he is stealing our opportunities. He must go back to Zimbabwe.' (Respondent 8)

- 'Many South Africans, they don't trust outsiders, so I don't think they will show that person ubuntu.' (Respondent 15)

- 'It depends, if you are coming with money and your own opportunities then you won't be discriminated against, but if you are looking for a job then it becomes another story.' (Respondent 11)

I was particularly interested in the meanings attached to ubuntu that differed from the ideal in some respect:

- 'People say that the izinyoka' - that is ubuntu. They are sharing electricity because it belongs to all of us - even if they are doing it illegally.' (Respondent 5)

- 'Ubuntu is about looking after your family. My brother he got a job in government, he is an Assistant Director. He got a job there for me and for his wife and for her brother. If you have a job you must help others. That is ubuntu.' (Respondent 19)

- 'Maybe if you have some influence, you can make sure that people in your network have some access to business opportunities so that they can be empowered economically.' (Respondent 7)

\section{The loss of ubuntu}

What conclusions can be drawn from reflecting on these stories about ubuntu in South Africa, especially in light of the optimistic and pessimistic positions on the usefulness of ubuntu? What do the acts of un-ubuntu that dominate our news reveal? Tutu's (1999) reflections on the absence of ubuntu in certain African contexts are worth noting:

1. A Zulu word for people with illegal electrical connections. 
Where was ubuntu in the Belgian Congo in the early 1960's? Why did the Rwandans forget ubuntu in 1994 and instead destroy one another in the most awful genocide ...? I don't really know except to say that honoring ubuntu is clearly not a mechanical, automatic and inevitable process ... (p. 36)

Tutu asks pointed questions about a lack of reverence for life in communities that should be characterised by ubuntu. How can children dance around the burning corpse of someone who has been 'necklaced'? Why is the environment treated so badly, with so much littering and dumping in these communities? Tutu (2011) writes:

It seems to me that we in the black community have lost our ubuntu - our humaneness, caring, hospitality, our sense of connectedness, our sense that my humanity is bound up in your humanity. (p. 172)

There can be little doubt that both the force and meaning of ubuntu have been eroded in South Africa today, and in some cases even distorted to justify blatant corruption and nepotism.

The erosion of ubuntu could be understood by referring to a number of forces that have impacted on traditional African culture. Colonialism, Apartheid, globalisation, and the encroachment of materialism, individualism, and consumerism have all played a role in shaping contemporary African culture. Part of their legacy is surely this weakening and distortion of the meaning and practice of ubuntu. Tragically, this erosion is part of and arises from a broader, sustained assault on African culture and identity from colonialism and racism. Within the fabric of what could be viewed as normal social change are woven the often dominant threads of gross systemic evil perpetuated against black African people over sustained periods.

It is concerning that advocates of ubuntu do not seem to have given much attention to the impact that all of these forces have had on indigenous African cultures. From the comments of some scholars it seems that both the existence of $u b u n t u$ as a defining social value in African communities as well as its meaning within those communities is taken for granted (Masango 2006:930-931). It is simply assumed to be there, and to be passed down from one generation to the next in a relatively undiluted form. However, both the theoretical debate about ubuntu and the understandings of ubuntu expressed by people I interviewed suggest that that this is not the case. Ubuntu has a range of meanings in current discourse, some of which seem close to traditional understandings and others which have less savoury implications. Apart from its use in discourse, the many acts of violence, discrimination and exclusion that take place in African communities suggest that ubuntu has lost some of its power to shape the actions of people in South African society.

Is ubuntu still alive? Is it still expressed in South African society? The answer seems to be an equivocal, 'yes and no'. It is alive and it is dead; it is seen and it is not seen. Ubuntu exists tightly interwoven with un-ubuntu.
For me, the erosion of $u b u n t u$ becomes symbolic for a broader and deeper erosion of identity. To be black and South African is to experience deep and profound wounds. A scouring of identity has stripped life of meaning and robbed humanity of its dignity. Within this place of deep and profound loss, a re-imagining and recovery of $u b u n t u$ might offer hope for a recovery of dignity and meaning.

\section{Liminality: Ubuntu in transition}

Is it legitimate to propose that the meaning of $u b u n t u$ is in a state of transition and needs redefinition? Gade (2011:315316) has demonstrated that the way ubuntu has been understood has not been static. From an analysis of written discourses on $u b u n t u$ he observes five stages:

- Stage 1: A period in which ubuntu was defined as a human quality.

- Stage 2: A period in which ubuntu was defined as something either connected to, or identical to, a philosophy or an ethic.

- Stage 3: A period in which ubuntu was defined as African humanism.

- Stage 4: A period in which ubuntu was defined as a worldview.

- Stage 5: A period in which ubuntu was defined as something connected to the proverb 'umuntu ngumuntu ngabantu'.

Gade (2011) shows that the meaning of $u b u n t u$ has already been in a process of redefinition for some time. Enslin and Horsthemke (2004:551) point out that certain communitarian and Africanist advocates of ubuntu mistakenly view communal identities as fixed and fail to recognise that identities and cultural practices change and evolve.

The concept of liminality is useful for reflecting on the current state of ubuntu. Liminality was first described by Van Gennep (1960), and developed by Turner (1967; 1969). Turner (1969:94) observed three phases in transition experiences:

- separation - losing an old world

- margin (liminality) - entering an unknown world

- reaggregation - re-emerging into a new world.

For Turner (1967:94), the liminal functions as the period of transition from 'one type of stable or recurrant condition that is culturally recognised' to another. There is an instability associated with liminality because it is a stage of transition or a process of becoming. Turner (1969:95) describes liminal positions as 'neither here nor there; they are betwixt and between the positions assigned and arrayed by law, custom, convention, and ceremony'. Turner (1969:95) refers to this space as 'the realm of pure possibility'.

The term liminality is often used fairly loosely in discourse. Roxburgh (2005) defines it as the condition of being on the threshold or at the beginning of a process. Liminality can also be used to describe the space between historical periods, or cultural communities, in which political or cultural 
change takes place (Thomassen 2009). In such periods social hierarchies and traditions may be disrupted. Discontinuity and uncertainty create a space of indeterminacy, openness and flexibility in which new traditions and institutions may arise (Horvath, Thomassen \& Wydra 2009).

The notion of liminality is applicable to South African society in transition. To use narrative language, we are 'in between stories'. Our narratives of culture and identity have to some extent been lost $^{2}$. We are in an unsettled, uncomfortable transitional space. Between narratives of what was and what could be we find ourselves in a what is that is full of contradictions and loss.

The temptation in times of unsettled transition is to nostalgically invoke the past and attempt to return to what once was. Whether one agrees with the romantic revisions of African history that underlie narratives of return or not, it cannot be disputed that current social realities in most of Africa, and particularly in South Africa, are far removed from the revisionist picture or landscape. The ground has shifted. The nature and extent of the shifts is enormous. As in the legend of King Canute, where he sat on his throne on the beach and rebuked the incoming tide, forbidding it from wetting his feet, it would be naïve to imagine that we can stand at the threshold of social change and prevent it from making incursions on a preferred social reality. Equally, we cannot simply undo the damage of our country's violent and fractured past and the way it has shaped our present reality. To the extent that narratives of return are nostalgic attempts to recover to the past, they do not seem to offer answers for the present.

\section{Hope for ubuntu}

Roxburgh (2005:87-89) describes the challenge for Christian leadership in a liminal context and argues that rather than attempting to control and predict, or attempting to return to the safety of what worked in the past, leadership should be concerned with forming 'networks of discourse' that intentionally take people beyond simplistic 'us versus them' thinking. We are in a period of rapid, discontinuous change on multiple levels. Within this context an important task for leaders is to create spaces in which our society can be reimagined, and to facilitate the clarification and adoption of the social values that would support the kind of society we would like to build. If we reflect back on our best experiences of ubuntu, how can they shape and define the ubuntu we want to practice in our faith communities and our society? In addition to this, what does this re-imagined, re-membered ubuntu mean for the way we structure our economic activities, conduct our relationships, and view the resources that we occupy or use?

\footnotetext{
2.It could be argued that 'white' cultural identity in South Africa has suffered similar loss and erosion in a post-colonial, post-Aparthed, The and erosion in a post-colonial, post-Apartheid, globalised postmodern world. The cult is bey and the that offered security and a sense of personhood have been lost. It is beyond the scope of this paper to examine the process through which this took place, but white South Africans are also 'in between stories' and in need of new story of identity and belonging.
}

\section{Discursive leadership and ubuntu}

The lens of discursive leadership is helpful for conceptualising this task. Discursive Leadership explores the social, linguistic and cultural aspects of leadership. It focusses on discourse rather than the inner psychological world of the leader, both discourse as language used in ordinary social interaction and Discourse as systems of thought that provide the linguistic resources for communication (Fairhurst 2007).

Leadership is socially constructed by the leaders and their followers, influenced by intermediaries such as the media (Liu 2010). It is not necessarily the domain of the individual, but can be distributed quite widely amongst members of an organisation or community (Fairhurst 2007:6).

There is an increased depiction of leaders as 'managers of meaning' (Shotter \& Cunliffe 2003; Smircich \& Morgan 1982). The implications of constructionist views of leadership are that leaders must constantly enact their relationship to their followers and 'perform leadership in communication and through discourse' (Fairhurst 2007:5).

Leadership is a social activity that involves defining reality and making sense of it. It is an intentional facilitation of the social construction of reality. Leaders identify what is important and then find ways to communicate about the meaning of events and seek consensus (Pondy 1978; Smircich \& Morgan 1982; Weick 1979). Shotter (1993) sees leadership as 'practical authoring' where leaders, faced with conditions that they have not chosen, create a range of enabling constraints along with moral positions and are able to argue persuasively for these.

Social meanings emerge and are managed as different interpretations of events compete with each other in social interaction (Weick, Sutcliffe \& Obstfeld 2005). There are always a number of competing Discourses at play in any context. Fairhurst (2007:99) writes, 'Because subjects attain their identities by being represented discursively, identity becomes a contingent identification with a subject position in a competitive discursive field'.

Greater competition within the discursive field creates the possibility that people can break free from the way a Discourse defines them. Fairhurst (2007:99) writes, 'The presence of other meaning potentials, in effect, dislocates a subject's identities, which opens a space for contingency and choice'.

Discursive Leadership will approach ubuntu by offering new stories and metaphors, introducing new categories that have the potential to shape identity, or by reframing social questions and challenges in a manner that offers possibilities for different ways of knowing how to emerge. Discourses intersect transversally in a social context, and meaning is shaped by their confluence. Leadership involves provocatively and subversively introducing additional linguistic resources for meaning-making and emphasising their intersections with other Discourses. 


\section{Conclusion}

\section{Ubuntu, shared history and shared fate}

There is hope for the kind of liminal space in which we find ourselves, there is hope for a healing of identity (which surely must underpin any reinvigoration of $u b u n t u$ ), and there is hope for creating patterns of living which embody the notion of $u b u n t u$ in its most basic sense.

Roxburgh's challenge to Christian leaders within liminal spaces is to create networks of discourse that take people beyond simplistic thinking. Nostalgic attempts to return to the past are impossible, but discursive leadership will shape the conversations we are having in South Africa by introducing new linguistic resources for imagining the future. Discourses of deficit and loss can be replaced with discourses of possibility and hope - even as the tangible evidence suggests that such hope is impossible. This is the nature of faith.

Within a narrative framework, we become the stories we tell about ourselves. This necessitates critical reflection on the stories that currently dominate social discourse, especially within faith communities, and an intentional shaping of social discourse so that our stories are reshaped through the lens of the biblical narrative.

We do not only share a painful history in South Africa. Williams (2003) points out the nature of citizenship as shared fate. South Africans will share the fate that is going to result from the ways they navigate the present moment together. Perhaps a reinvention of ubuntu might help us navigate this shared moment in our history. Even if we can't recover ubuntu in its once pristine form, I have hope that certain kinds of conversations could help each of us connect with the other in a way that leads us to the creation and embrace of social values that reflect our location in Africa, honour the pain and struggle of our past, but that ultimately provide impetus to shape a shared fate that we anticipate rather than one we fear.

\section{Acknowledgements}

The financial assistance of the National Research Foundation (NRF) towards this research is hereby acknowledged. Opinions expressed and conclusions arrived at, are those of the author and are not necessarily to be attributed to the NRF.

\section{Competing interests}

The author declares that he has no financial or personal relationships which may have inappropriately influenced him in writing this article.

\section{References}

Bekker, T., 2006, 'The re-emergence of ubuntu: A critical analysis', South African Public Law 21(2), 333-344.

Broodryk, J., 2002, Ubuntu: Life lessons from Africa, Ubuntu School of Philosophy, Pretoria.
Chikanda, N.E., 1990, 'Shared values and ubuntu', paper presented at Kontak Conference, HSRC, Pretoria.

Cornell, D. \& Van Marle, K., 2005, 'Exploring ubuntu: Tentative reflections', African Human Rights Law Journal 5(2), 195-220.

Department of Education's Service Delivery Plan, 2007/2008, viewed 09 January 2015, from http://www.dpsa.gov.za/batho-pele/docs/SDIP/mpumalanga/education. pdf.

De Gruchy, J.W., 2011, 'Transforming traditions: Doing theology in South Africa today', Journal of Theology for Southern Africa 139, 7-17.

Enslin, P. \& Horsthemke, K., 2004, 'Can ubuntu provide a model for citizenship education in African democracies?', Comparative Education 40(4), 545-558. http://dx.doi.org/10.1080/0305006042000284538

Fairhurst, G.T., 2007, Discursive leadership: In conversation with leadership psychology, Sage, Thousand Oaks, C.A.

Forster, D.A., 2010, 'African relational ontology, individual identity, and Christian theology: An African theological contribution towards an integrated relational ontological identity', Theology 113, 243-253.

Gade, C.B.N., 2011, 'The historical development of the written discourses on ubuntu', South African Journal of Philosophy 30(3), 303-329. http://dx.doi.org/10.4314/ sajpem.v30i3.69578

Gathogo, J., 2008, 'African philosophy as expressed in the concepts of hospitality and ubuntu', Journal of Theology for Southern Africa 130, 39-53.

Higgs, P., 2003, 'African philosophy and the transformation of educational discourse in South Africa', Journal of Education 30, 5-22.

Horvath, A., Thomassen, B. \& Wydra, H., 2009, 'Introduction: Liminality and cultures of change', International Political Anthropology 2(1), 3-5.

Interim Constitution of the Republic of South Africa, Act 200 of 1993, viewed 04 February 2015, from http://www.constitutionalcourt.org.za/site/constitution/ english-web/interim/.

Khoza, R., 1994, African humanism, Ekhaya Promotions, Diepkloof Extension, South Africa.

Letseka, M., 2012, 'In defence of ubuntu', Studies in Philosophy and Education 31(1), 47-60. http://dx.doi.org/10.1007/s11217-011-9267-2

Liu, H., 2010, 'When leaders fail: A typology of failures and framing strategies', Management Communication Quarterly 24(2), 323-259. http://dx.doi. org/10.1177/0893318909359085

Louw, D.J., 2001, 'Ubuntu and the challenges of multiculturalism in post-Apartheid South Africa', Quest: An African Journal of Philosophy XV(1-2), 15-36.

Lutz, D.W., 2009, 'African ubuntu philosophy and global management', Journal of Business Ethics 84(Suppl. 3), 314-328. http://dx.doi.org/10.1007/s10551-0090204-z

Makhudu, N., 1993, 'Cultivating a climate of cooperation through ubuntu', Enterprise $68,40-41$.

Masango, M., 2006, 'African spirituality that shapes the concept of ubuntu', Verbum et Ecclesia 27(3), viewed 7 January 2015, from http://www.ve.org.za/index.php/ VE/article/view/195/149

Matolino, B. \& Kwindingwi, W., 2013, 'The end of ubuntu', South African Journal of Philosophy 32(2), 197-205. http://dx.doi.org/10.1080/02580136.2013.817637

Mbigi, L., 1992, 'Unhu or Ubuntu: The basis for effective HR management', People's Dynamics, 20-26.

Mcunu, T.N., 2004, 'The dignity of the human person: A contribution of the theology of ubuntu to theological anthropology', MTh thesis, Dept. of Systematic Theology, University of South Africa.

Metz, T., 2007, 'Toward an African moral theory', The Journal of Political Philosophy 15(3), 321-341. http://dx.doi.org/10.1111/j.1467-9760.2007.00280.x

Mkhize, N., 2008, 'Ubuntu and harmony: An African approach to morality and ethics', in R. Nicolson (ed.), Persons in community: African ethics in a global culture, pp. 35-44, University of KwaZulu-Natal Press, Scottsville.

Mokgoro, Y., 1998, 'Ubuntu and the law in South Africa', Buffalo Human Rights Law Review 15, 1-6.

Mnyaka, M. \& Motlhabi, M., 2009, 'Ubuntu and its socio-moral significance', in M.F. Murove (ed.), African ethics: An anthology of comparative and applied ethics, pp. 63-84, University of KwaZulu-Natal Press, Scottsville.

Murithi, T., 2006, 'African approaches to building peace and social solidarity', African Journal on Conflict Resolution 6(2), 9-34.

Naude, P.J., 2013, 'Am I my brother's keeper? An African reflection on humanisation', Nederduitse Gereformeerde Teologiese Tydskrif 54, 241-253, viewed 17 July 2014, from http://ngtt.journals.ac.za/pub/article/view/360.

Nkondo, G.M., 2007, 'Ubuntu as public policy in South Africa: A conceptual framework', International Journal of African Renaissance Studies 2(1), 88-100.

Pondy, L.R., 1978, 'Leadership is a language game', in J.M.W. McCall \& M.M. Lombardo (eds.), Leadership: Where else can we go?, Duke University Press, Durham.

Prinsloo, E.D., 1998, 'Ubuntu culture and participatory management', in P.H. Coetzee \& A.P.J. Roux (eds.), The African philosophy reader, pp. 41-51, Routledge, London.

Roxburgh, A.J., 2005, The sky is falling!?! Leaders lost in transition, ACl Publishing, Eagle.

South African Press Association, 2014, 'Platinum strike makes times tougher', viewed 13 January 2015, from http://www.iol.co.za/business/platinum-strike-makestimes-tougher-1.1693039\#.U-m_8vmSy_c. 
Setiloane, G.M., 1998, 'Towards a biocentric theology and ethic: Via Africa', in C.W. du Toit (ed.), Faith science and African culture: African cosmology and Africa's
contribution to science, pp. 73-84, Research institute for Theology and Religion, contribution to science, $\mathrm{pp}$. 73-84,
University of South Africa, Pretoria.

Shotter, J., 1993, Conversational realities: Constructing life through language, Sage, London.

Shotter, J. \& Cunliffe, A.L., 2003, 'Managers as practical authors: Everyday conversations for action', in D. Holman \& R. Thorpe (eds.), Management and language, Sage Publications, London.

Shutte, A., 1993, Philosophy for Africa, University of Cape Town Press, Cape Town.

Shutte, A., 2001, Ubuntu: An ethic for a new South Africa, Cluster Publications, Pietermaritzburg.

Smircich, L. \& Morgan, G., 1982, 'Leadership: The management of meaning', Journal of Applied Behavioral Science 18, 257-273. http://dx.doi. org/10.1177/002188638201800303

Thomassen, B., 2009, 'The uses and meanings of liminality', International Political Anthropology 2(1), 5-28, viewed 13 April 2015, from http://www.international. politicalanthropology.org/images/articles/2009_1/ipa_journal_1_2009 thomassen.pdf

Turner, V.W., 1967, The forest of symbols, Ithaca, New York.

Turner, V.W., 1969, The ritual process: Structure and anti-structure, Aldine Publishing Company, Chicago.
Tutu, D.M., 1999, No future without forgiveness, Rider, London.

Tutu, D.M., 2011, God is not a Christian and other provocations, Harper Collins, New York.

Van den Heuwel, H., Mangaliso, M.P. \& Van de Bunt, L. (eds.), 2007, Prophecies and protests: Ubuntu in glocal management, UNISA Press, Pretoria.

Van Gennep, A., 1960, The rites of passage, Routledge, London.

Venter, E., 2004, 'The notion of ubuntu and communalism in African educational discourse', Studies in Philosophy and Education 23, 149-160. http://dx.doi. org/10.1023/B:SPED.0000024428.29295.03

Weick, K.E., 1979, The social psychology of organising, Random House, New York

Weick, K.E, Sutcliffe, K.M. \& Obstfeld, D., 2005, 'Organising and the process of sensemaking', Organization Science 16, 409-421. http://dx.doi.org/10.1287/ orsc. 1050.0133

West, A., 2014, 'Ubuntu and business ethics: Problems, perspectives and prospects', Journal of Business Ethics 121, 47-61. http://dx.doi.org/10.1007/s10551-0131669-3

Williams, M.S., 2003, 'Citizenship as identity, citizenship as shared fate, and the functions of multicultural education', in W. Feinberg \& K. McDonough (eds.), Citizenship and education in liberal-democratic societies: Teaching collective identities and cosmopolitan values, Oxford University Press, Oxford. http://dx.doi. org/10.1093/0199253668.003.0009 